Received: 17 December 2018, Revised: 31 December 2018 Accepted: 7 January 2019, Published: 28 January 2019 Available online at: http://e-journal.unair.ac.id/index.php/IMHSJ

\title{
HUBUNGAN USIA MENARCHE DENGAN KEJADIAN ENDOMETRIOSIS
}

\section{ASSOCIATION BETWEEN AGE OF MENARCHE WITH INCIDENCE OF ENDOMETRIOSIS}

\author{
Sri Purwati Puji Lestari ${ }^{1}$, Jimmy Yanuar Annas ${ }^{2}$, Juniastuti $^{2}$
}

\author{
1. Program Studi Pendidikan Bidan Fakultas Kedokteran Universitas Airlangga \\ 2. Fakultas Kedokteran Universitas Airlangga \\ Alamat korespondensi: \\ Jl. Rencong I No. 23 Tebel Gedangan Sidoarjo. \\ Email : sri.purwati.puji-2017@fk.unair.ac.id
}

\begin{abstract}
Abstrak
Latar belakang : Endometriosis adalah penyakit ginekologi yang bersifat menahun dan progresif dengan angka kejadiannya mengalami peningkatan dari tahun ke tahun namun penyebabnya sebagian besar masih belum diketahui. Usia menarche adalah salah satu faktor resiko yang berhubungan dengan kejadian endometriosis. Tujuan penulisan ini adalah untuk mengetahui hubungan antara usia menarche dengan kejadian endometriosis di Rumkital Dr. Ramelan Surabaya. Metode : Penelitian ini merupakan penelitian analitik retrospective dengan pendekatan case control. Kelompok kasus adalah wanita yang telah menjalani operasi kandungan dengan hasil Patologi Anatomi menunjukkan endometriosis dan kelompok kontrol adalah pasien wanita yang telah menjalani operasi laparaskopi MOW (Metode Opetratif Wanita). Sampel yang diambil sebanyak 70 responden (35 kasus, 35 kontrol) selama periode tahun 2017-2018 dengan teknik purposive sampling berdasarkan kriteria inklusi.. Analisa data menggunakan uji chi square pada tingkat kemaknaan $\alpha 0,05$. Hasil : Responden dengan endometriosis sebagian besar mengalami menarche pada usia 12-13 tahun (62,9\%). Usia menarche tidak memiliki hubungan yang signifikan dengan kejadian endometriosis $(p=0,484)$. Kesimpulan: Tidak ada hubungan antara usia menarche dengan kejadian endometriosis di Rumkital Dr. Ramelan Surabaya.
\end{abstract}

Kata kunci : endometriosis, usia menarche

\begin{abstract}
Background: Endometriosis is a chronic and progressive gynecological disease with an increased incidence every year but the cause is largely unknown. Age of menarche is one of the risk factors associated with the incidence of endometriosis. The purpose of this study was to determine the association between age of menarche the incidence of endometriosis in Dr. Ramelan Hospital Surabaya. Method: This was a retrospective analytic study with a case control approach. The case group was women who had undergone uterine surgery with Anatomical Pathology results showing endometriosis and the control group were women who had undergone laparoscopic tuba ligation. 70 respondents (35 cases, 35 controls) taken during the period of 2017-2018 with a purposive sampling technique based on inclusion criteria. Analyzed data used chu square test at significant level of $\alpha$ 0,05. Results: Most respondent who got endometriosis had menarche at 12-13 years old $(62.9 \%)$. The age of menarche had no significant association with the incidence of endometriosis $(p$ = 0.484). Conclusion: We found no association between age of menarche and the incidence of endometriosis with the incidence of endometriosis in the Dr. Ramelan Hospital Surabaya.
\end{abstract}

Keyword : endometriosis, age of menarche.

\section{PENDAHULUAN}

e-ISSN 2656-7806 C 2019

Published by Universitas Airlangga .This is an Open Access (OA) article distributed under the terms of the Creative Commons Attribution Share-Alike 4.0 International License 
Endometriosis adalah penyakit ginekologi yang bersifat menahun dan progresif dengan angka kejadiannya mengalami peningkatan dari tahun ke tahun. Penyakit ini merupakan suatu gangguan ginekologi yang ditandai dengan adanya jaringan endometrium di luar kavum uteri yang dapat memicu terjadinya reaksi inflamasi (Hestiantoro $\mathrm{dkk}, 2014)$. Endometriosis disebut sebagai esterogen dependent disease karena tumbuh kembangnya jaringan ektopik endometrium dirangsang oleh hormon esterogen (ESHRE, 2013). Angka kejadian endometriosis sulit diketahui, namun diduga berkisar antara 6-10\% pada populasi umum (Giudice et al, 2004). Diperkirakan angka kejadian lebih tinggi di negara Asia (Asia tenggara dan Jepang) yang mencapai 15\% (Yamamoto et al, 2017). Di Indonesia sendiri, angka kejadiannya sangat beragam dan bergantung pada banyak faktor.

Peningkatan kejadian endometriosis yang ditemukan dari tahun ke tahun patut diperhatikan dengan memahami faktor resiko yang meningkatkan kejadian endometriosis ini. Salah satu faktor resiko yang secara konsisten berhubungan dengan endometriosis adalah karakteristik menstruasi yaitu menarche dini, siklus haid yang pendek, durasi lama haid yang lebih panjang dan volume haid yang berlebihan. Menarche adalah periode menstruasi yang pertama terjadi pada masa pubertas seorang perempuan. Penelitian menunjukkan kecenderungan anak perempuan mencapai usia menarche semakin dini diberbagai negara termasuk Indonesia (Sohn, 2015). Usia dini saat menarche, yang didefinisikan sebagai usia saat pertama kali menstruasi $\leq 11$ tahun (Gaudineau et al, 2010), dapat meningkatkan pajanan seorang wanita terhadap menstruasi selama masa reproduksinya dan akibatnya meningkatkan risiko endometriosis. Usia menarche yang lebih dini akan memiliki peluang lebih besar terpapar esterogen pada setiap siklus menstruasinya sehingga kemungkinan terjadi retrograde menstruasi lebih besar dan meningkatkan resiko endometriosis (Saha, 2016). Tujuan dari penulisan ini adalah untuk menentukan hubungan antara usia menarche dengan kejadian endometriosis di Rumkital Dr. Ramelan Surabaya. 


\section{METODE}

Rancangan penelitian yang digunakan adalah analitik, dengan case-control retrospective study. Populasi pada penelitian ini adalah wanita yang telah menjalani operasi kandungan periode tahun 2017-2018. Teknik sampel yang digunakan adalah purposive sampling. Besar sampel dihitung menggunakan rumus besar sampel penelitian analitik didapatkan hasil 35 responden dengan perbandingan 1:1 untuk sampel kontrol. Penelitian dilakukan di ruang operasi kandungan Rumkital Dr. Ramelan Surabaya.

Variabel bebas dalam penelitian ini adalah usia menarche, sedangkan Variabel terikat adalah endometriosis. Tekhnik pengumpulan data menggunakan data sekunder yaitu rekam medik. Berikut definisi operasional dari variabel penelitian.

\section{Tabel 1 Definisi operasional variabel penelitian}

\begin{tabular}{|c|c|c|c|c|}
\hline Variabel & Definisi & Parameter & Alat Ukur & Skala \\
\hline $\begin{array}{l}\text { Variabel bebas } \\
\text { Usia menarche }\end{array}$ & $\begin{array}{l}\text { Usia responden saat } \\
\text { pertama kali } \\
\text { mendapatkan } \\
\text { menstruasi. }\end{array}$ & $\begin{array}{l}\text { - } \quad<12 \text { tahun } \\
\text { - } \quad 12-13 \text { tahun } \\
\text { - } \quad \geq 14 \text { tahun }\end{array}$ & Rekam medik & Ordinal \\
\hline $\begin{array}{l}\text { Variabel terikat } \\
\text { Endometriosis }\end{array}$ & $\begin{array}{l}\text { Gangguan ginekologi } \\
\text { pada wanita yang } \\
\text { ditandai dengan adanya } \\
\text { jaringan endometrium } \\
\text { diluar kavum uteri dan } \\
\text { dibuktikan dengan hasil } \\
\text { PA untuk kelompok } \\
\text { kasus dan dengan } \\
\text { laparaskopi untuk } \\
\text { kelompok kontrol }\end{array}$ & $\begin{array}{l}\text { 1. Ya } \\
\text { 2. Tidak }\end{array}$ & Rekam medik & Nominal \\
\hline $\begin{array}{r}\text { Pengum } \\
\text { akukan deng } \\
\text { nalisis meng }\end{array}$ & $\begin{array}{l}\text { an data dilakukan } \mathrm{p} \\
\text { tahapan editing, co } \\
\text { nakan uji chi squar }\end{array}$ & $\begin{array}{l}\text { ada bulan Mei } \\
\text { ding, entry dat } \\
(\alpha=0,05,\end{array}$ & $\begin{array}{l}\text { 2019. Pengol } \\
\text { dan clening } \\
=95 \% \text { ) denga }\end{array}$ & $\begin{array}{l}\text { han data } \\
\text { emudian } \\
\text { bantuan }\end{array}$ \\
\hline
\end{tabular}




\section{HASIL DAN PEMBAHASAN}

\section{Karakteristik responden}

Tabel 2. Karakteristik responden dengan kejadian endometriosis

\begin{tabular}{|c|c|c|c|c|c|}
\hline \multirow{3}{*}{ Karakteristik } & \multicolumn{4}{|c|}{ Endometriosis } & \multirow{3}{*}{ P value } \\
\hline & \multicolumn{2}{|c|}{ Yes } & \multicolumn{2}{|c|}{ No } & \\
\hline & $\mathrm{n}$ & $(\%)$ & $\mathrm{n}$ & $(\%)$ & \\
\hline \multicolumn{6}{|l|}{ Usia } \\
\hline $20-40$ & 14 & 40 & 17 & 48,6 & 0,470 \\
\hline$>40$ & 21 & 60 & 18 & 51,4 & \\
\hline \multicolumn{6}{|l|}{ Paritas } \\
\hline Nulipara & 13 & 37,1 & 0 & 0 & \\
\hline Primipara & 10 & 28,6 & 0 & 0 & 0,0001 \\
\hline Multipara & 12 & 34,3 & 35 & 100 & \\
\hline \multicolumn{6}{|l|}{ Siklus haid } \\
\hline$\geq 27$ hari & 21 & 60 & 2 & 5,7 & 0,0001 \\
\hline$>27$ hari & 14 & 40 & 33 & 94,3 & \\
\hline \multicolumn{6}{|l|}{ Lama haid } \\
\hline$<7$ hari & 14 & 40 & 15 & 42,9 & 0,808 \\
\hline$\geq 7$ hari & 21 & 60 & 20 & 57,1 & \\
\hline \multicolumn{6}{|l|}{ Riwayat kontrasepsi } \\
\hline \multirow{3}{*}{$\begin{array}{ll}\text { Ya } & \text { Hormonal } \\
& \text { Non hormonal }\end{array}$} & 13 & 37,1 & 30 & 85,7 & \\
\hline & 8 & 22,9 & 3 & 8,6 & 0,0001 \\
\hline & 14 & 40 & 2 & 5,7 & \\
\hline
\end{tabular}

Tabel 1 menunjukkan bahwa dari beberapa karakteristik responden yang mempunyai hubungan signifikan $(\mathrm{p}<0,005)$ antara lain paritas, siklus menstruasi, dan riwayat kontrasepsi. Usia dan lama haid tidak memiliki hubungan yang signifikan dengan kejadian endometriosis $(\mathrm{p}>0,05)$.

\section{Tabel 3. Hubungan Usia Menarche dengan endometriosis}

\begin{tabular}{|c|c|c|c|c|c|}
\hline \multirow{2}{*}{ Usia Menarche } & \multicolumn{2}{|c|}{ Kasus } & \multicolumn{2}{|c|}{ Kontrol } & \multirow{2}{*}{ p value } \\
\hline & $\mathbf{n}$ & $\%$ & $\mathbf{n}$ & $\%$ & \\
\hline$<12$ tahun & 3 & 8,6 & 4 & 11,4 & \multirow{4}{*}{0,484} \\
\hline 12-13 tahun & 22 & 62,9 & 17 & 48,6 & \\
\hline$\geq 14$ tahun & 10 & 28,6 & 14 & 40 & \\
\hline Total & 35 & 100 & 35 & 100 & \\
\hline
\end{tabular}

Tabel 2 menunjukkan bahwa kejadian menarche sebagian besar dialami oleh responden dengan usia menarche 12-13 tahun. Hasil uji chi square menunjukkan $p$ value $>0,005$ yang artinya usia menarche belum tentu faktor resiko.

Hasil penelitian ini sesuai dengan hasil penelitian Peterson et al (2013) yang melaporkan bahwa tidak ada hubungan antara endometriosis dengan siklus menstruasi termasuk lama menstruasi, dan usia saat menarche. Penelitian yang 
dilakukan oleh Treolar et al (2010) menyatakan bahwa terdapat hubungan terbalik antara usia menarche dan endometriosis dimana menarche setelah usia 14 tahun menurunkan resiko endometriosis (OR 0,3; 95\% CI 0,1-0,6). Sebuah systematic review dan meta-analysis oleh Nnoaham et al (2012) terhadap 18 penelitian kasuskontrol melaporkan bahwa terdapat peningkatan resiko endometriosis pada menarche dini walaupun hanya sedikit oleh karena variasi metode dan klasifikasi dari kontrol. Namun, tidak sesuai dengan hasil penelitian oleh Mukti (2014) yang menyatakan bahwa ada hubungan antara usia menarche dengan endometriosis ( $p$ value 0,007$)$.

Teori Sampson menyatakan bahwa endometriosis disebabkan karena menstruasi retrograde dimana wanita dengan peluang menstruasi yang lebih banyak meningkatkan resiko endometriosis (Treolar et al, 2010). Usia menarche yang lebih dini akan memiliki peluang lebih besar terpapar esterogen pada setiap siklus menstruasinya sehingga kemungkinan terjadi retrograde menstruasi lebih besar dan meningkatkan resiko endometriosis. Beberapa penelitian telah melakukan observasi level estradiol dan esterogen yang lebih tinggi pada wanita yang mengalami menarche dini. Penemuan ini menunjukkan bahwa estradiol berperan penting pada pembentukan endometriosis dimana dapat menjelaskan bahwa paparan esterogen yang lebih tinggi disebabkan oleh menarche yang lebih dini sehingga meningkatkan resiko endometriosis (Saha, 2016).

Hasil penelitian ini menunjukkan usia menache mungkin buka satu-satunya faktor resiko endometriosis tetapi dapat dipengaruhi faktor lain dari data karakteristik responden yang berhubungan dengan kejadian endometriosis seperti paritas, siklus haid dan pemakaian kontrasepsi hormonal.

\section{SIMPULAN DAN SARAN}

Kejadian endometriosis sebagian besar terjadi pada responden yang mengalami menarche usia 12-13 tahun. Usia menarche tidak memiliki hubungan yang signifikan dengan endometriosis.

Peneliti selanjutnya dapat meneliti tentang faktor-faktor lain yang mempengaruhi kejadian endometriosis dengan metode penelitian yang berbeda supaya didapatkan hasil penelitian lebih akurat dan informatif. 


\section{DAFTAR PUSTAKA}

Bouzari, Z., Yazdani, S., Aharngarkolaee, ZH., Zeinalzadeh, M \& Hajian, K. (2016). The Comparison of Menstrual Characteristics and BMI in Women with Endometriosis and Without Endometriosis. Women's health \& gynecology, 2(8), pp 1-6.

European Society of Human Reproduction and Embriology (ESHRE). (2013). Guideline : management of women with endometriosis. ESHRE endometriosis guideline development group. [online] diperoleh dari https://www.eshre.eu/Guidelines-and-Legal [diakses pada 12 februari 2019].

Gaudineau, A., Ehlinger, V., Vayssiere, C. et al. (2010). Factors associated with early menarche : result from the French health behavior in school-aged children (HBSC) study. BMC public health, $10: 175$, pp.1-2.

Hediger, M.L., Hartnett, H.J., Louis, G.M.B. (2005). Association of endometriosis with body size and figure. Fertility and sterility, 84(5), pp. 1366-1374.

Hestiantoro, A., Natadisastra, M., Wiweko, B. dkk. (2013). Current updates on polycystic ovary syndrome, endometriosis, adenomyosis. Jakarta : Sagung seto. Hlm 73-102.

Jacoeb, T.Z. \& Hadisaputra, W. (2009). Penanganan endometriosis panduan klinis dan algoritme. Jakarta : CV. Sagung Seto.

Liu, Yong \& Zhang, Weiyuan. (2017). Association between body mass index and endometriosis risk : a meta-analysis. Oncotarget, 8(29), pp. 46928-46936.

Mukti, P. (2014). Faktor risiko kejadian endometriosis. Unnes journal of public health, 3 (3), pp 1-10. http://journal.unnes.ac.id/sju/index.php/ujph

Nnoaham, K. E., Webster, P., Kumbang, J., Kennedy, S. H., \& Zondervan, K. T. (2012). Is early age at menarche a risk factor for endometriosis? A systematic review and meta-analysis of case-control studies. Fertility and sterility, 98(3), 702-712.e6. doi:10.1016/j.fertnstert.2012.05.035

Peterson, C.M., Johnstone, E.B., Hammoud, A. O. et al. (2013). Risk factors associated with endometriosis : importance of study population for characterizing disease in the ENDO study. American journal of obstetrics and gynecology, $208 \quad$ (6), pp. $451 \quad$ e1-451 e11. DOI:10.1016/j.ajog.2013.02.040

Saha, R., Kuja-Halkola, R., Tornvall, P \& Marions, L. (2017). Reproductive and lifestyle factors associated endometriosis in a large cross-sectional population sample. Journal of women's health, 26 (2), pp. 152-158.

Sohn, K. (2015). The trend in age at menarche in Indonesia : birth cohorts 19441988. Journal of biosocial science, 47 (3), pp. 407-412.

Speroff, Lion \& Fritz, M.A. (2011). Clinical gynesology and infertility $8^{\text {th }}$ edition. Philadelphia : Wolters Kluwer Lippincott Williams \& Wilkins. pp. 12331234.

Treolar, S.A., Bell, T.A., Nagle, C.M. et al. (2010). Early menstrual characteristic associated with subsequent diagnosis of endometriosis. American journal of obstetrics and gynecology, 202 (6), pp. 534 e1-534 e6. DOI: https://doi.org/10.1016/j.ajog.2009.10.857

Yamamoto, A., Johnstone, E.B., Bloom, M.S. et al. (2017). A higher prevalence of endometriosis among asian women does not contribute to poorer IVF 
Indonesian Midwifery and Health Sciences Journal

outcomes. Journal of assisted reproduction and genetics, 34 (6), pp. $765-$ 774. 